\title{
PENGARUH PENDAPATAN RUMAH TANGGA TERHADAP POLA KONSUMSI: STUDI PADA DOSEN DAN STAFF UIN AR-RANIRY
}

\author{
Devi Mulia Sari \\ Prodi Tekhnologi Informasi, Politeknik Aceh \\ Devi@politeknikaceh.ac.id \\ Cut Yunina Eriva \\ Prodi Akuntansi Sektor Publik \\ Cut.yunina@politeknikaceh.ac.id
}

\begin{abstract}
Abstrak
Pendapatan akan mempengaruhi perbedaan pola konsumsi masyarakat. Konsumsi masyarakat Kota Banda Aceh meningkat dari tahun ketahun. Peningkatan ini terjadi pada konsumsi makanan dan non makanan. Namun, konsumsi non makanan lebih tinggi dari pada makanan setiap tahunnya. Penelitian ini dilakukan untuk mengetahui pengaruh tingkat pendapatan rumah tangga dosen dan tenaga kependidikan terhadap prilaku konsumsi pada dosen dan tenaga kependidikan UIN Ar-raniry. Penelitian ini menggunakan pendekatan kuantitatif. Popolasi dalam penelitian ini merupakan Dosen dan Staff pada UIN AR Raniry Banda Aceh. Sampel ditentukan secara kebetulan yang ditemui dan masuk ke dalam kategori populasi (Incidential Sampling) yang berjumlah 92 orang. Data dianalisis dengan menggunakan regresi linier sederhana. Hasil penelitian ini menunjukkan bahwa pengaruh pendapatan rumah tangga terhadap pola konsumsi berpengaruh signifikan.
\end{abstract}

Kata Kunci: Pendapatan Rumah Tangga, Pola Konsumsi

\begin{abstract}
Civil Servants (PNS) earn different levels of income. Differences in income will affect differences in people's consumption patterns. The consumption of the people of Banda Aceh has increased from year to year. This increase occurred in food and non-food consumption. However, non-food consumption is higher than food each year. This research was conducted to determine the effect of the level of household income of lecturers and education staff on the consumption behavior of lecturers and educational staff of UIN Ar-raniry. This study uses a quantitative approach. Popolation in this research is Lecturers and Staff at UIN AR Raniry Banda Aceh. The sample was determined by chance that they encountered and entered into the population category (Incidential Sampling), amounting to 92 people. Data were analyzed using simple linear regression. The results of this study indicate that the effect of household income on consumption patterns has a significant effect.
\end{abstract}

Keywords: Household Income, Consumption Pattern.

\section{A. PENDAHULUAN}

Setiap individu melakukan kegiatan konsumsi untuk memenuhi kebutuhan hidupnya. Dalam proses memenuhi kebutuhan hidupnya, manusia memerlukan pengeluaran pendapatan untuk konsumsi. Pengeluaran tersebut sekurang-kurangnya dapat memenuhi tingkat kebutuhan minimum yang dibutuhkan sehingga konsumsi 
merupakan hal yang mutlak diperlukan setiap orang untuk bertahan hidup.

Berdasarkan hasil penelitian Badan Pusat Statistik (BPS) yang tercantum pada laporan Aceh dalam angka terlihat bahwa masyarakat Kota Banda Aceh mengeluarkan biaya konsumsi non makanan lebih tinggi dari pada biaya konsumsi makanan. Konsumsi non makanan ini dapat berupa pakaian, tempat tinggal, transportasi, komunikasi, pendidikan, kesehatan dan lainnya. Biaya konsumsi non makanan yang semakin tinggi, dan sebaliknya biaya konsumsi makanan cenderung lebih rendah memperlihatkan tingkat kesejahteraan semakin membaik.

Tabel 1

Konsumsi Rata-Rata per Kapita Penduduk Kota Banda Aceh Tahun 2012-2016

\begin{tabular}{|l|r|r|l|}
\hline \multirow{2}{*}{ Tahun } & \multicolumn{3}{|c|}{ Konsumsi rata-rata per kapita (Rupiah) } \\
\cline { 2 - 4 } & \multicolumn{1}{|c|}{ Makanan } & $\begin{array}{c}\text { Non } \\
\text { Makanan }\end{array}$ & \multicolumn{1}{l|}{ Jumlah } \\
\hline 2012 & 599.349 & 698.069 & 1.297 .418 \\
\hline 2013 & 650.180 & 793.527 & 1.443 .707 \\
\hline 2014 & 688.649 & 865.327 & 1.553 .977 \\
\hline 2015 & 612.781 & 964.521 & 1.577 .302 \\
\hline 2016 & 685.799 & 996.241 & 1.682 .040 \\
\hline
\end{tabular}

Sumber Data: BPS Kota Banda Aceh Tahun 2017

Tingkat konsumsi yang tinggi, akan tinggi perubahan kegiatan ekonomi dan pendapatan nasional. Hal tersebut diakibatkan oleh perubahan belanja agregat. Pertumbuhan ekonomi suatu negara sangat dipengaruhi oleh perubahan pola konsumsi masyarakat dalam jangka panjang. Pola konsumsi merupakan salah satu indikator untuk mengukur tingkat kesejahteraan masyarakat.

Dosen dan tenaga kependidikan memperoleh pendapatan setiap bulan sesuai dengan masa kerja dan pangkat. Pendapatan dosen diterima selama satu bulan sekali dan akhir semester. Dosen juga memperoleh pendapatan tambahan dari penelitian dan pengabdian masyarakat serta sertifikasi dosen profesional. Sehingga tingkat pendapatan dosen yang berbeda-beda menyebabkan perbedaan pada pola konsumsi. Pendapatan yang mereka peroleh tersebut, digunakan untuk keperluan konsumsi sesuai dengan tingkat kebutuhan. Tingkat kebutuhan paling dasar (primer) untuk mempertahankan kehidupan secara wajar menggambarkan mutu kehidupan masyarakat.

Pola konsumsi yang terus meningkat diharapkan seiring dengan pendapatan dosen dan tenaga kependidikan yang terus meningkat. Namun apabila pendapatan dosen dan tenaga kependidikan konstan, maka pola konsumsi harus diturunkan. Hal tersebut dapat menggangu tingkat kesejahteraan masyarakat.

Tujuan dari penulisan ini adalah untuk mengetahui bagaimana dan berapa besar pengaruh pendapatan terhadap konsumsi pada dosen dan tenaga kependidikan Universitas Islam Negeri Ar-Raniry Banda Aceh.

\section{B. KAJIAN PUSTAKA}

Kajian literatur berisi kajian berbagai teori yang mendasari munculnya penelitian yang berisi berbagai landasan teori dari variable yang digunakan dalam penelitian ini. Penulisan menggunakan menggunakan format APA $\sigma^{\text {th }}$ Edition (American Psychological Association). Untuk Satu sumber kutipan dengan satu penulis: (Jones, 1998: 25). Satu sumber kutipan dengan dua penulis: (Jones dan Freeman, 1980: 20). Satu sumber kutipan dengan lebih dari dua penulis: (Jones et al., 1997: 25). Dua sumber kutipan dengan penulis berbeda: (Jones 1987: 27; Freeman 1988: 56). Dua sumber kutipan dengan penulis sama: (Jones 1988; 1999). Jika tahun publikasinya sama: (Jones, 1999a; 1999b). Sumber kutipan yang berasal dari pekerjaan suatu institusi ditulis dengan menyebutkan akronim institusi yang bersangkutan, misalnya (MES 2012). Atau menggunakan footnote ${ }^{1}$. Setiap penulisan

1 Badan Pusat Statistik Aceh, Jumlah Dan Persentase Penduduk Miskin Provinsi Aceh Maret 2000 - Maret 2017, diakses pada website resmi aceh.bps.go.id pada 6 oktober 2017. 
harus konsisten menggunakan footnote atau bodynote $^{2}$

\section{Konsumsi}

Sitepu (2016) dalam penelitiannya menyebutkan bahwa tujuan konsumsi adalah mencari kepuasan (utility) tertinggi. Konsumsi barang dan jasa ditentukan berdasarkan tingkat kepuasan tersebut. Konsumen akan cenderung memilih barang dan jasa yang memiliki nilai kepuasannya paling tinggi. Konsumen memiliki pengetahuan tentang barang atau jasa alternatif yang dapat memaksimalkan kebutuhan.

Untuk memenuhi kebutuhan konsumsinya, masyarakat perlu membayar dengan pendapatan. Pendapatan yang diperoleh mereka berasal dari usaha-usaha produksinya. Petani menanam padi untuk mendapatkan pendapatan yang dapat membiayai konsumsinya. Semua kegiatan konsumsi membutuhkan biaya. Setiap rumah tangga akan mengeluarkan biaya belanja dari pendapatan yang diperolehnya untuk memenuhi kebutuhan hidup.

BPS (2017) mengemukakan, klasifikasi jenis-jenis pengeluaran konsumsi rumah tangga yang dibedakan menjadi dua yaitu jenis pengeluaran untuk kebutuhan makanan dan kebutuhan non makanan. Pengeluaran konsumsi makanan adalah jumlah uang dari pendapatan yang digunakan untuk membeli makanan dalam hal ini, beras, daging, ikan, telur, susu, sayur-sayuran, kacangkacangan, buah-buahan, minyak, bahanbahan minuman, bumbu-bumbuan, dan termasuk juga makanan dan minuman yang telah jadi. Sementara pengeluaran konsumsi untuk non makanan adalah jumlah uang dari pendapatan yang digunakan untuk membeli berbagai kebutuhan non makanan, dalam hal ini barang-barang, seperti pembayaran listrik, air, telepon, pulsa handphone, sewa rumah, bahan bakar untuk memasak, surat kabar, transportasi (bensin dan ongkos angkutan), termasuk di dalamnya pelayanan kesehatan, pendidikan, dan rekreasi.

2 http://medanbisnisdaily.com diakses pada tanggal 5 Oktober Tahun 2017 pukul 10.20 wib.
Nababan (2013) Jenis konsumsi sangat beragam, baik konsumsi pokok, sekunder maupun barang-barang mewah. Akan tetapi jenis konsumsi yang diutamakan adalah kebutuhan pokok. Apabila seseorang memiliki pendapatan lebih dari biasanya selanjutnya kebutuhan sekunder atau barang mewah dikonsumsikan setelah kebutuhan primer. Manusia dalam memenuhi kebutuhan terlebih dahulu perlu melakukan usaha, melalui usaha diperoleh pendapatan yang digunakan untuk konsumsi.

Sehingga dapat disimpulkan, biaya yang dikeluarkan rumah tangga setiap bulan untuk konsumsi seluruh anggota rumah tangga merupakan pengeluaran konsumsi rumah tangga.

\section{Fungsi Konsumsi}

Pengeluaran konsumsi merupakan fungsi dari pendapatan yang habis pakai, namun dalam perkembangan selanjutnya konsumsi juga dianggap merupakan fungsi dari faktor-faktor yang dipengaruhi oleh tingkat pendapatan. Dalam melakukan pengeluaran konsumsi konsumen harus memperhatikan tingkat pendapatan yang diperoleh. Konsumen yang melakukan pengeluaran harus memilih konsumsi yang paling dibutuhkan. Setelah konsumsi tersebut terpenuhi haruslah sisa pendapatan yang ada digunakan untuk lain yang bersifat penunjang, misalnya untuk memperoleh barang-barang mewah dan dapat juga dijadikan sebagai tabungan dari selisih pendapatan yang tidak digunakan oleh konsumsi. Adanya kelebihan pendapatan masyarakat untuk tabungan, maka menggambarkan masyarakat tersebut sudah sejahtera karena dapat memenuhi kebutuhan yang diinginkan untuk dikonsumsi.

Menurut (Muttaqin, 2015), Tingkat pendapatan yang diperoleh sangat berpengaruh terhadap konsumsi. Untuk dapat mengkonsumsi, seseorang harus mempunyai pendapatan, besar kecilnya pendapatan seseorang sangat menentukan tingkat konsumsinya. Pendapatan yang kecil hanya mampu mengkonsumsi lebih sedikit. Hubungan konsumsi dengan tingkat 
pendapatan sebagaimana dijelaskan Maynard Keynes yaitu:

$$
\mathrm{C}=\mathrm{a}+\mathrm{bY}
$$

Di mana:

$\mathrm{C}=$ Pengeluaran untuk konsumsi

$\mathrm{a}=$ Besarnya konsumsi pada saat pendapatan tidak ada

$\mathrm{b}=$ Besarnya tambah konsumsi yang disebab kan tambah pendapatan, disebut hasrat berkonsumsi marjinal

\section{Pendapatan}

Pendapatan seseorang atau individu dapat diartikan sebagai jenis pendapatan masyarakat, termasuk pendapatan yang diperoleh tanpa melakukan kegiatan apapun, yang diterima oleh penduduk. Pendapatan pribadi merupakan pendapatan dari hasil usaha yang diperoleh individu atau kelompok rumah tangga dan digunakan untuk memenuhi kebutuhan sehari-hari.

(Danil, 2013) Pendapatan sesuatu negara atau pendapatan yang diperoleh masyarakat akan dapat meningkatkan tabungan masyarakat itu sendiri. Karena untuk mempercepat pembangunan ekonomi memerlukan pembentukan modal yang besar, pengumpulan modal dalam lembaga keuangan merupakan salah satu faktor untuk membiaya pembangunan ekonomi. Akan tetapi penyediaan dana yang dipergunakan untuk pembentukan modal dalam usaha untuk mempercepat pembangunan tersebut berasal dari tabungan masyarakat yang berhasil dihimpun oleh perbankan.

Salah satu kriteria maju tidaknya suatu daerah adalah tingkat pendapatan. Bila pendapatan suatu daerah relatif rendah, dapat dikatakan bahwa kemajuan dan kesejahteraan tersebut akan rendah pula. Demikian pula bila pendapatan masyarakat suatu daerah relatif tinggi, maka tingkat kesejahteraan dan kemajuan daerah tersebut tinggi pula.

Pendapatan PNS adalah penerimaan dari gaji tetap, atau balas jasa dari hasil usaha yang diperoleh setelah dipotong pajak PPH oleh setiap pegawai dalam satu bulan. Pendapatan yang diperoleh pegawai negeri sipil dari usaha sampingan adalah pendapatan tambahan yang merupakan penerimaan lain dari luar aktivitas pokok atau pekerjaan pokok. Pendapatan sampingan yang diperoleh secara langsung dapat digunakan untuk menunjang atau menambah pendapatan pokok

\section{Pola Penggunaan Pendapatan untuk Konsumsi}

Distribusi pendapatan adalah penyaluran atau pembelanjaan PNS untuk kebutuhan konsumsi. Kurangnya distribusi pendapatan dapat menimbulkan daya beli rendah, terjadinya tingkat kemiskinan, ketidakadilan, kelaparan dan lain-lain yang akhirnya akan menimbulkan anti pati golongan masyarakat yang berpendapatan rendah terhadap yang berpendapatan tinggi, sehingga akan menimbulkan kecemburuan sosial di dalam masyarakat.

Tingkat konsumsi memberikan gambaran tingkat kemakmuran seseorang atau suatu masyarakat. Semakin tinggi tingkat konsumsi, semakin sejahtera seseorang. Sebaliknya semakin rendah tingkat konsumsi, berarti semakin miskin. Untuk dapat mengkonsumsi seseorang harus mempunyai pendapatan.

Muttaqim (2015) mungungkapkan tingkat pendapatan seseorang merupakan penentu utama dari konsumsi rumah tangga. Besarnya pendapatan akan mempengaruhi besarnya konsumsi yang dapat dinikmati seseorang. Konsumsi tersebut meliputi kebutuhan primer, sekunder dan tersier. Orang yang berpenghasilan rendah cenderung akan mengkonsumsi kebutuhan primer sebagai dasar hidupnya. Sehingga, Pendapatan merupakan indikator batasan konsumsi rumah tangga.

\section{DATA DAN METODOLOGI}

Data yang digunakan dalam penelitian ini bersumber dari dosen dan tenaga kependidikan UIN Ar-Raniry. Sampel ditentukan secara kebetulan yang ditemui dan masuk ke dalam kategori populasi (Incidential Sampling). Berdasarkan metode incendetial sampling diperoleh sebanyak 92 orang yang terdiri dari dosen dan tenaga kependidikan UIN Ar-Raniry yang tersebar 
disetiap fakultas dan biro. Skala yang digunakan dalam instrument penelitian ini adalah skala likert.

Teknik pengumpulan data yang digunakan adalah kuesioner (angket). Kuesioner merupakan teknik pengumpulan data dengan cara memberi seperangkat pertanyaan atau pernyataan tertulis kepada responden untuk menjawabnya.

Penelitian ini merupakan penelitian dengan pendekatan kuantitatif. Metode analisis yang digunakan dalam penelitian ini adalah analisis regresi linier sederhana. Data diolah dengan menggunakan program software SPSS (Statistical Package for Social Sciences) Versi 18.

Analisis data dilakukan setelah proses pengumpulan data selesai. Data yang sudah terkumpulkan dilakukan proses pengecekan dan penyesuaian untuk memudahkan proses pemberian kode dan pemrosesan data dengan teknik statistik. Data tersebut perlu diedit terlebih dahulu agar terhindar dari kemungkinan kekeliruan, kekurangan atau tidak konsisten dalam proses pencatatan. Proses pengeditan data ini perlu diperhatikan kelengkapan data yang telah diisi dengan sempurna dan dapat dipahami secara jelas.

\section{HASIL DAN PEMBAHASAN}

Statistik deskriptif dalam penelitian ini dapat dilihat pada Tabel 1.

Tabel 1. Statistik Deskriptif Variabel Pendapatan Rumah Tangga

\begin{tabular}{|l|c|c|}
\hline Pendapatan & Frekuensi & Persentase \\
\hline$<$ Rp.2.500.000 & 28 & 30,4 \\
\hline $\begin{array}{l}\text { Rp. } 2.500 .001- \\
\text { Rp. } 3.500 .000\end{array}$ & 29 & 31,5 \\
\hline $\begin{array}{l}\text { Rp. 3.500.001 - } \\
\text { Rp. 4.500.000 }\end{array}$ & 24 & 26,1 \\
\hline $\begin{array}{l}\text { Rp. 4.500.001 - } \\
\text { Rp. 5.500.000 }\end{array}$ & 8 & 8,7 \\
\hline > Rp. 5.500.000 & 3 & 3,3 \\
\hline
\end{tabular}

Berdasarkan Tabel 2, Pendapatan di bawah Rp.2.500.000 sebanyak 30,4\%. Responden yang memiliki pendapatan antara Rp.2.500.000-Rp.3.500.000 sebanyak 31,5 $\%$. Responden yang memperoleh pendapatan Rp.3.500.000-Rp.4.500.000 sebanyak 26,1\%. Responden yang memperoleh pendapatan
Rp.4.500.000-Rp.5.500.000 sebanyak 8,7\%. Responden yang memiliki penghasilan di atas Rp.5.500.000 sebanyak 3,3\%.

Tabel 3. Statistik Deskriptif Variabel Pola Konsumsi

\begin{tabular}{|c|c|c|c|c|c|c|}
\hline No & Pertanyaan & $\mathrm{SS}$ & $\mathrm{S}$ & $\mathrm{R}$ & $\mathrm{TS}$ & STS \\
\hline 1 & $\begin{array}{l}\text { Setiap pendapatan } \\
\text { tambahan akan } \\
\text { dialokasikan untuk } \\
\text { konsumsi barang } \\
\text { mewah }\end{array}$ & 4 & 26 & 15 & 36 & 11 \\
\hline & Rata-rata (M) & & & 2,74 & & \\
\hline 2 & $\begin{array}{l}\text { Mengkonsumsi } \\
\text { karena keinginan } \\
\text { nafsu }\end{array}$ & 25 & 46 & 13 & 6 & 2 \\
\hline & Rata-rata (M) & & & 3,93 & & \\
\hline 3 & $\begin{array}{lr}\text { Dalam } & \text { kegiatan } \\
\text { konsumsi } & \text { saya } \\
\text { tidak memaksa } & \\
\text { kehendak } & \\
\end{array}$ & 29 & 43 & 9 & 4 & 7 \\
\hline & Rata-rata (M) & & & 3,90 & & \\
\hline 4 & $\begin{array}{lr}\text { Dalam kegiatan } \\
\text { konsumsi } \\
\text { lakukan karena ada } \\
\text { diskon walaupun } \\
\text { belum dibutuhkan }\end{array}$ & 25 & 46 & 8 & 5 & 8 \\
\hline & Rata-rata (M) & & & 3,82 & & \\
\hline 5 & $\begin{array}{l}\text { Konsumsi saya rela } \\
\text { harus berhutang }\end{array}$ & 7 & 7 & 10 & 55 & 11 \\
\hline & Rata-rata (M) & & & 2,41 & & \\
\hline 6 & $\begin{array}{l}\text { mengkonsumsi } \\
\text { barang mewah dari } \\
\text { tabungan }\end{array}$ & 9 & 53 & 14 & 13 & 3 \\
\hline & Rata-rata (M) & & & 3,57 & & \\
\hline 7 & $\begin{array}{l}\text { konsumsi saya } \\
\text { selalu } \\
\text { mempertimbangka } \\
\text { n kehalalannya } \\
\end{array}$ & 57 & 26 & 3 & 1 & 5 \\
\hline & Rata-rata (M) & & & 4,40 & & \\
\hline
\end{tabular}

Tabel 3 menunjukkan bahwa persepsi dosen UIN Ar-Raniry terhadap item pertanyaan setiap pendapatan tambahan akan dialokasikan untuk konsumsi barang mewah yaitu pada tingkat kategori sedang $(\mathrm{M}=2,74)$. Artinya, ada dosen dan tenaga kependidikan yang berpersepsi setiap pendapatan tambahan akan dialokasikan untuk konsumsi barang mewah. Hal ini dapat menimbulkan efek buruk terhadap manusia karena tidak efektif dan efisien dalam pemanfaatan sumber daya.

Item pertanyaan mengkonsumsi karena keinginan nafsu yaitu pada tingkat kategori sedang $(\mathrm{M}=3$, 93). Artinya, ada dosen dan tenaga kependidikan yang berpersepsi bahwa 
melakukan konsumsi hanya karena keinginan nafsu dan bukan kebutuhan. Sehingga pendapatan yang dikonsumsi habis untuk halhal yang tidak diperlu dan merugikan.

Item pertanyaan dalam kegiatan konsumsinya tidak memaksa kehendak yaitu pada tingkat kategori sedang $(\mathrm{M}=3,90)$. Artinya, ada dosen dan tenaga kependidikan yang berpersepsi bahwa untuk kegiatan konsumsi mereka tidak memaksa kehendak untuk mengikuti hawa nafsunya.

Item pertanyaan dalam kegiatan konsumsi dilakukan karena ada diskon walaupun belum dibutuhkan yaitu pada tingkat kategori sedang $(\mathrm{M}=3,82)$. Artinya, ada dosen dan tenaga kependidikan yang berpersepsi bahwa mereka tidak mempertimbangkan kebutuhan dalam melakukan konsumsi yang terpenting adalah harga yang murah.

Item pertanyaan untuk konsumsi rela harus berhutang yaitu pada tingkat kategori sedang $(M=2,41)$. Artinya, sedikit dosen dan tenaga kependidikan yang berpersepsi bahwa untuk memenuhi kebutuhan konsumsi mereka rela harus berhutang.

Item pertanyaan mengkonsumsi barang mewah dari tabungan yaitu pada tingkat kategori sedang $(\mathrm{M}=3,57)$. Artinya, ada dosen dan tenaga kependidikan yang berpersepsi bahwa tabungan dapat digunakan untuk konsumsi barang mewah.

Item pertanyaan konsumsi selalu mempertimbangkan kehalalannya yaitu pada tingkat kategori tinggi $(\mathrm{M}=4,4)$, artinya mayoritas dosen dan tenaga kependidikan selalu mempertimbangkan kehalalannya pada saat konsumsi.

Hasil regresi linier sederhana pengaruh pendapatan rumah tangga terhadap pola konsumsi dapat dilihat pada Tabel 4.

Tabel 4

Hasil Regresi Linier Sederhana Pengaruh

Pendapatan Rumah Tangga terhadap Pola Konsumsi

\begin{tabular}{ccccc}
\hline Model & R & $\begin{array}{c}\mathbf{R} \\
\text { Square }\end{array}$ & $\begin{array}{c}\text { Adjusted } \\
\text { R Square }\end{array}$ & $\begin{array}{c}\text { Std. Error of } \\
\text { the Estimate }\end{array}$ \\
\hline 1 & $.126^{\mathrm{a}}$ & .016 & .005 & .53006 \\
\hline
\end{tabular}

Tabel di atas menunjukkan bahwa nilai koefisien korelasi/hubungan (R) sebesar 140
0,126 , yang berarti hubungan variabel bebas (pendapatan) dan terikat (konsumsi) sebesar 12, $6 \%$. Dijelaskan besarnya prosentase pengaruh variabel bebas terhadap variabel terikat yang disebut koefisien determinasi yang merupakan hasil dari penguadratan $\mathrm{R}$. Dari hasil yang diperoleh tersebut koefisien determinasi $\left(\mathrm{R}^{2}\right)$ sebesar 0, 016, dapat diartikan bahwa adanya pengaruh variabel bebas (pendapatan) dan terikat (konsumsi) sebesar 1,6\%. Nilai ini menunjukkan hubungan positif antara pendapatan dengan konsumsi.

Semakin tinggi tingkat pendapatan dosen dan tenaga kependidikan UIN ArRaniry, maka akan diikuti meningkatnya konsumsi. Konsumsi yang meningkat tidak signifikan dan termasuk dalam kategori rendah. Konsumsi tersebut mengarah pada kebutuhan sekunder, bukan pada kebutuhan pokok lagi.(Anggraini, Hayati, \& Si, n.d.)

Pengeluaran konsumsi bukan makanan akan meningkat seiring dengan meningkatnya pendapatan. Pendapatan yang digunakan untuk konsumsi makanan cenderung turun jika pendapatan meningkat. Konsumsi makanan memiliki hubungan terbalik antara persentase kenaikan pendapatan. Meningkatnya pendapatan akan mengakibatkan persentase yang digunakan untuk sandang dan pelaksanaan rumah tangga cenderung konstan. Pendapatan tersebut cenderung digunakan untuk pendidikan, kesehatan dan rekreasi.

Pendapatan yang meningkat atau tambahan tidak digunakan secara konsumtif oleh dosen dan tenaga kependidikan UIN ArRaniry. Dosen dan tenaga kependidikan UIN Ar-Raniry selalu mempertimbangkan kehalalan suatu makanan yang dikonsumsi. Mereka melakukan kegiatan konsumsi secara tidak berlebihan. Setiap pendapatan tambahan yang diterima tidak dialokasikan untuk mengkonsumsi barang mewah dan tidak mengikuti keinginan nafsu. Namun, mereka rela melakukan konsumsi walau harus berhutang. 


\section{E. KESIMPULAN}

Pendapatan rumah tangga berpengaruh positif terhadap pola konsumsi dosen dan staff UIN Ar-Raniry. Hal ini menunjukkan bahwa pendapatan rumah tangga berpengaruh signifikan terhadap konsumsi bagi Dosen dan staff UIN Ar-Raniry. Bertambahnya pendapatan rumah tangga mereka akan bertambah pula pola konsumsinya.

Staff dan dosen yang memiliki penghasilan pada tingkat I yaitu dengan pendapatan dibawah Rp. 2.500.000,- maka disarankan memiliki penghasilan tambahan untuk memenuhi kebutuhan. Untuk memenuhi kebutuhan yang dikonsumsi juga berpengaruh dengan beberapa faktor lainnya, seperti jumlah tanggungan, tabungan dan sedekah. Diharapkan peneliti selanjutnya dapat melakukan penelitian dengan menambahkan beberapa factor lainnya.

\section{DAFTAR PUSTAKA}

Anggraini, Nita dan Hayati, Banatul, "Hubungan Kausalitas Dari Tingkat Pendidikan, Pendapatan, Dan Konsumsi Terhadap Jumlah Penduduk Miskin Di Provinsi Jawa Tengah." Undergraduate thesis, Fakultas Ekonomika dan Bisnis. (2012) http://eprints.undip.ac.id/35763/

(diakses 18 August 2017).

Anggraini, N., Hayati, B., \& Si, M. (n.d.). Hubungan kausalitas dari tingkat pendidikan, pendapatan, dan konsumsi terhadap jumlah penduduk miskin di provinsi jawa tengah, 1-27.
Danil, M. (2013). Pengaruh Pendapatan Terhadap Tingkat Konsumsi Pada Pegawai Negeri Sipil Di Kantor Bupati Kabupaten Bireuen, (7), 33-41.

Muttaqim, H. (2014). Analisis Pengaruh Pendapatan Kepala Keluarga Terhadap Konsumsi Rumah Tangga Di Kecamatan Bandar Sakti Kota Lhokseumawe Tahun 2014.

Nababan, S. S. M. (2013). Pendapatan dan jumlah tanggungan pengaruhnya terhadap pola konsumsi PNS dosen dan tenaga kependididkan pada fakultas ekonomi dan bisnis Universitas Sam Ratulangi Manado. Jurnal EMBA, 1(4), 2130-2141.

Anggraini, N., Hayati, B., \& Si, M. (n.d.). Hubungan kausalitas dari tingkat pendidikan, pendapatan, dan konsumsi terhadap jumlah penduduk miskin di provinsi jawa tengah, 1-27.

Danil, M. (2013). Pengaruh Pendapatan Terhadap Tingkat Konsumsi Pada Pegawai Negeri Sipil Di Kantor Bupati Kabupaten Bireuen, (7), 33-41.

Muttaqim, H. (2014). Analisis Pengaruh Pendapatan Kepala Keluarga Terhadap Konsumsi Rumah Tangga Di Kecamatan Bandar Sakti Kota Lhokseumawe Tahun 2014.

Nababan, S. S. M. (2013). Pendapatan dan jumlah tanggungan pengaruhnya terhadap pola konsumsi PNS dosen dan tenaga kependididkan pada fakultas ekonomi dan bisnis Universitas Sam Ratulangi Manado. Jurnal EMBA, 1(4), 2130-2141. 